\title{
Identification and localization of adrenomedullin-storing cardiac mast cells
}

\author{
ANNA S. BELLONI ${ }^{1}$, LUCIA PETRELLI ${ }^{1}$, DIEGO GUIDOLIN ${ }^{1}$, RENZO DE TONI ${ }^{2}$, SERGIO BOVA ${ }^{3}$, \\ RAFFAELLA SPINAZZI $^{1}$, GINO GEROSA ${ }^{4}$, GIAN PAOLO ROSSI ${ }^{2}$ and GASTONE G. NUSSDORFER ${ }^{1}$ \\ Departments of ${ }^{1}$ Human Anatomy and Physiology, Section of Anatomy, ${ }^{2}$ Clinical and Experimental Medicine, \\ ${ }^{3}$ Pharmacology and Anesthesiology, and ${ }^{4}$ Cardiological, Thoracic and Vascular Sciences, \\ School of Medicine, University of Padua, I-35121 Padua, Italy
}

Received December 6, 2005; Accepted January 5, 2006

\begin{abstract}
Adrenomedullin (AM), a potent vasodilatory hypotensive peptide, is expressed in the heart, where it is known to play a protective action. Light-microscopy immunocytochemistry (ICC) demonstrated the presence of AM immunoreactivity not only in the coronary-vessel wall and ventricular myocytes of the human and rat heart, but also in sparse voluminous cells located in the perivascular space. These cells displayed the same location of toluidine blue-positive mast cells, and electron microscopy ICC showed AM-immunogold staining over the granules of rat cardiac mast cells. The incubation of rat left ventricle fragments with the mast-cell histamine releaser compound 48/80 evidenced groups of AM-positive cells undergoing degranulation and caused an increase of approximately $50 \%$ in the AM concentration in the incubation medium. Collectively, our findings provide evidence that at least a subset of cardiac mast cells are able to synthesize and store AM, and upon stimulation to release it near coronary arterioles and venules.
\end{abstract}

\section{Introduction}

Adrenomedullin (AM) is a long-lasting vasodilatory hypotensive peptide, which is abundantly expressed in human and rat coronary vessels and cardiomyocytes (reviewed in refs. 1,2). In the course of immunocytochemical studies on the effect of endothelin-1 (ET-1) on AM content and distribution in the rat heart $(3,4)$, we observed the presence of sporadic voluminous intensely AM-positive cells prevalently located in the perivascular space. Although the bulk of evidence indicates that AM is secreted constitutively from the cells of cardiovascular system, this finding was not surprising because

Correspondence to: Professor Gastone G. Nussdorfer, Department of Human Anatomy and Physiology, Section of Anatomy, Via Gabelli 65, I-35121 Padua, Italy

E-mail: gastone.nusdorfer@unipd.it

Key words: adrenomedullin, mast cells, heart, human, rat other tissues have been reported to possess AM-storing cells: e.g. F cells of pancreatic islets, diffuse endocrine cells of the rat stomach, apocrine cells of the mammary gland and type I glomus cells of the rat carotic body $(1,5,6)$.

Subsequent studies showed that these AM-positive cells stain with toluidine blue, and undergo a decrease in number is response not only to ET-1, but also to the mast cell degranulator compound 48/80 (7). Based on these findings and on their prevalent location near blood-vessel walls, the hypothesis has been advanced that AM-storing cells are cardiac mast cells. However, this contention lacks definitive proof. Hence, we carried out additional light and electron microscopic immunocytochemical studies and functional experiments to address this issue.

\section{Materials and methods}

Tissue and reagents. Adult male Sprague-Dawley rats (140-160 g body weight) were purchased from Charles-River (Como, Italy). Rats were decapitated, and their heart promptly removed. Bioptic fragments of the heart interventricular septum were obtained from patients undergoing periodic control after heart transplantation. The study protocol was approved by the local Ethics Committees for Human and Animal Studies. Human and rat AM, and rabbit anti-rat AM1-50 and anti-human AM1-52 polyclonal antibodies were obtained from Phoenix Pharmaceuticals (Belmont, CA). Secondary goat anti-rabbit IgG peroxidase-conjugated antibodies were provided by Dako (Glostrup, Denmark) or Chemicon International (Temecula, CA), and secondary goat anti-rabbit IgG 20-nm immunogold-conjugated antibodies by British Biocell International (Cardiff, UK). Sigma Fast 3',3'diaminobenzidine $0.7 \mathrm{mg}$ tablets (DAB tablet set), compound 48/80, phosphate-buffered saline (PBS) and all other laboratory reagents were puchased from Sigma-Aldrich Corp. (St. Louis, MO).

Light microscopy. Left ventricle wall of the heart of 8 rats was chopped into $1-\mathrm{mm}^{3}$ fragments, which were put in KrebsRinger bicarbonate buffer ( $\mathrm{pH} 7.4$ ) and incubated for $30 \mathrm{~min}$ in the presence or absence of compound 48/80 $(50 \mu \mathrm{g} / \mathrm{ml})$. The incubation was carried out at $37^{\circ} \mathrm{C}$ in an atmosphere of 

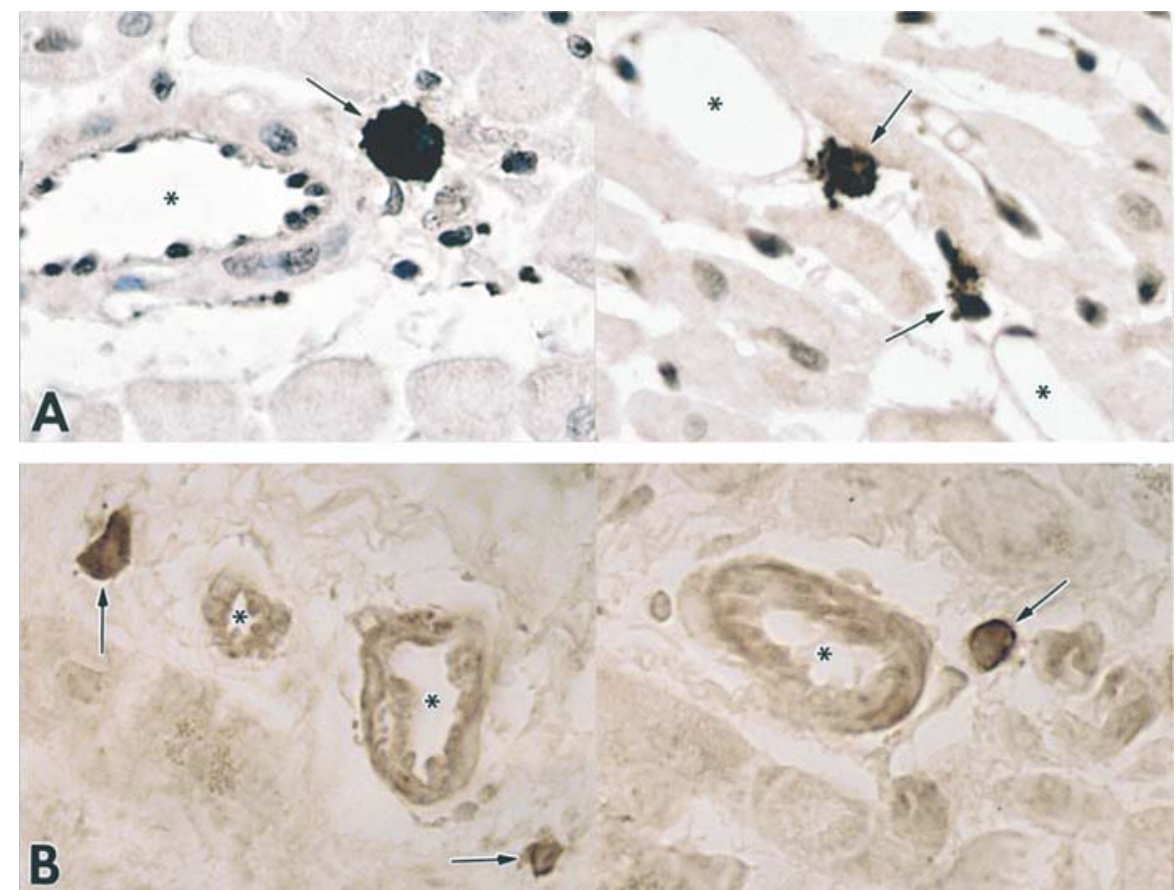

Figure 1. Six- $\mu$ m thick paraffin sections of the rat (A) and human heart (B), showing AM-storing (DAB-positive) cells (arrowheads) located near coronary venules and arterioles $(*)$, respectively. Moderate DAB positivity is also displayed by cardiomyocytes and arteriole walls (B). Magnification x 500.
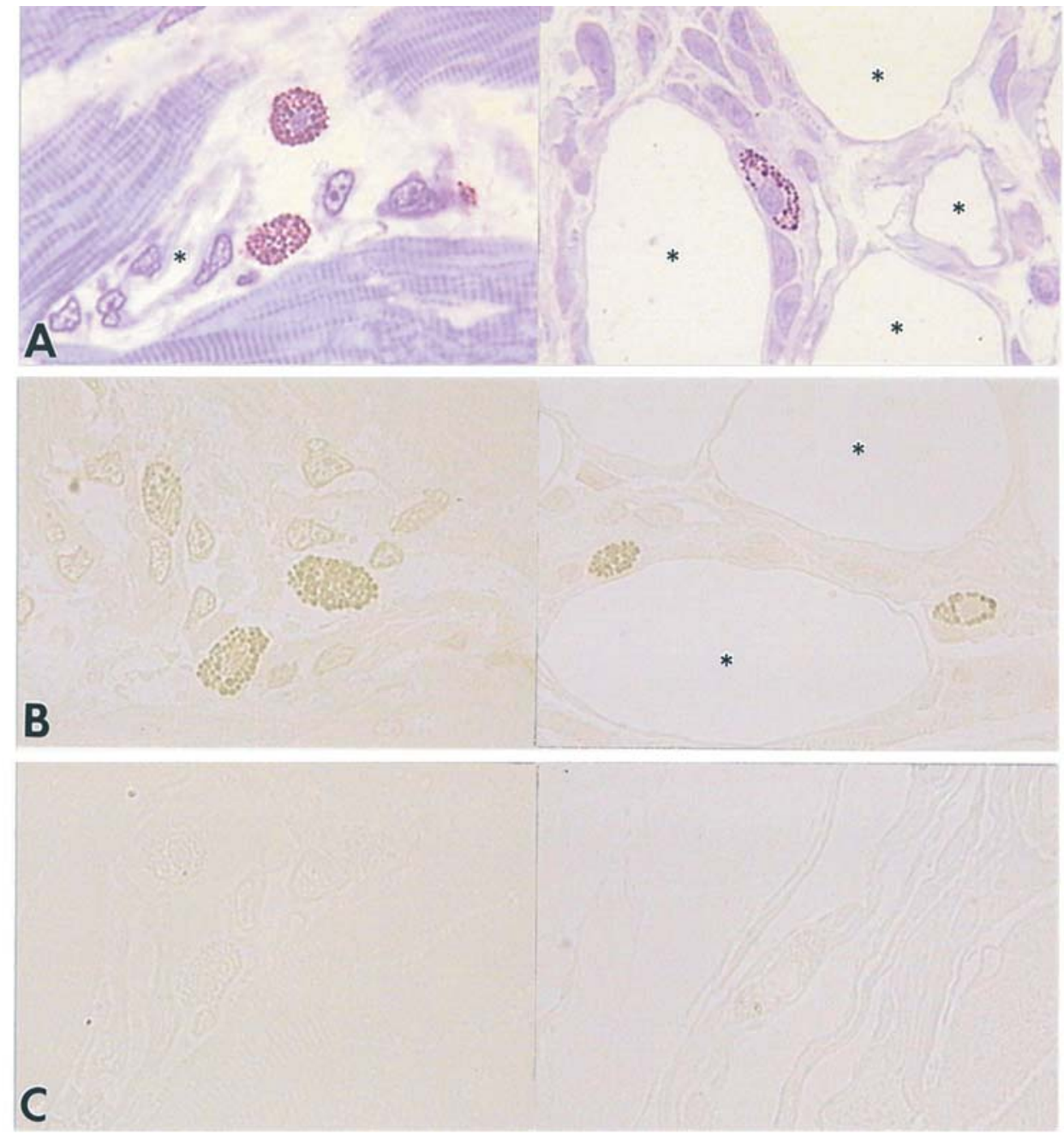

Figure 2. Two- $\mu \mathrm{m}$ thick plastic sections of the rat heart, showing that toluidine blue-stained (A) and AM-immunostained cells (B) have the same location in the perivascular space near the coronary vessels $(*)$. Negative control carried out by omission of the primary antibody (C). Magnification $\mathrm{x} 1,000$. 


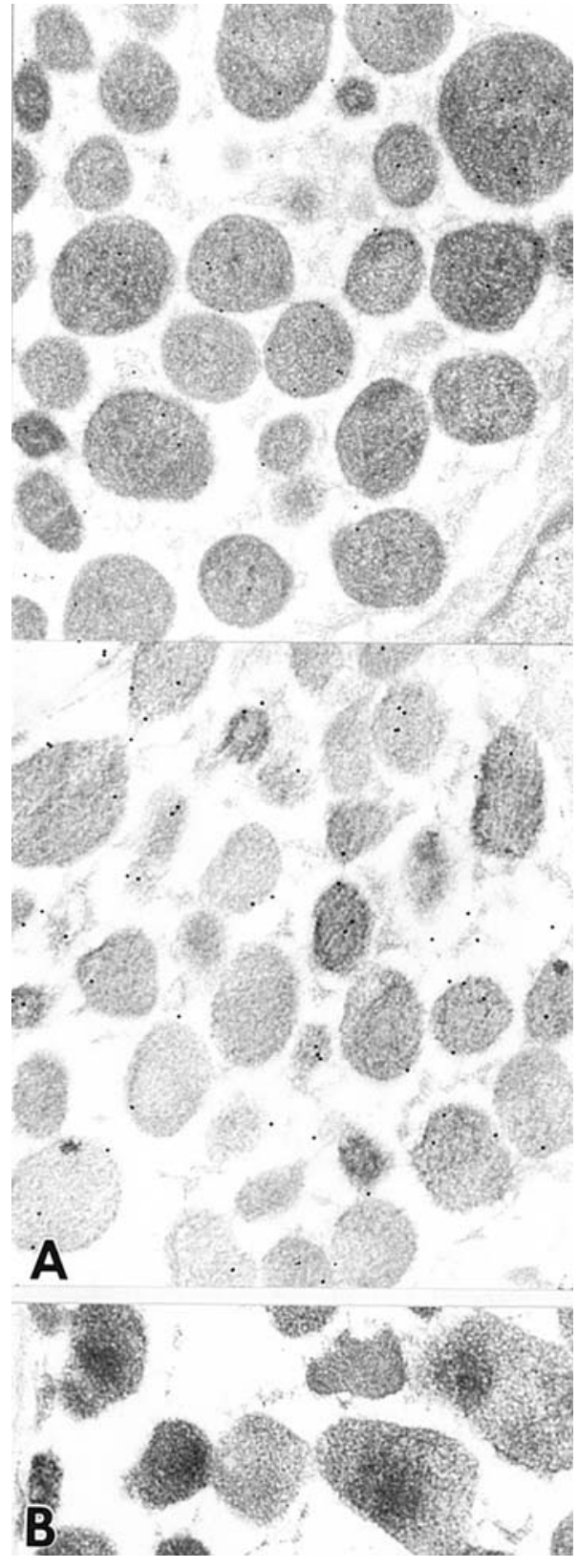

Figure 3. Electron micrograph of a mast cell of the rat heart, showing the almost exclusive granular location of AM-positive material, as evidenced by the 20-nm immunogold particles (A). Negative control carried out using primary antibody preabsorbed with AM excess (B). Magnification x25,500.

95\% air-5\% $\mathrm{CO}_{2}$, then fragments were weighed and incubation medium was collected and stored at $-80^{\circ} \mathrm{C}$ until AM RIA. Rat heart and human heart biopsy fragments were fixed in $4 \%$ paraformaldehyde in PBS for $5 \mathrm{~h}$, and then embedded in paraffin. Six $-\mu \mathrm{m}$ thick sections were cut, and stored for immunocytochemistry (ICC).

Electron microscopy. Left ventricle fragments of other rats were fixed overnight in $4 \%$ paraformaldehyde- $0.2 \%$ glutaraldehyde in $0.1 \mathrm{M}$ phosphate buffer, dehydrated, and then embedded in the acrylic resin L.R. White (London Resin Company, London, UK). Sections $(2-\mu \mathrm{m})$ were cut with a Reichert-Jung SuperNova ultramicrotome, stained with toluidine blue and observed with a light microscope to recognize mast cells (8). Adjacent 60-nm ultrathin sections were then cut and collected on 400-mesh nickel grids. Sections were stored until ICC.

Immunocytochemistry. Paraffin $(6-\mu \mathrm{m})$ and plastic $(2-\mu \mathrm{m})$ sections were exposed to $3 \%$ hydrogen peroxide for $5 \mathrm{~min}$ at room temperature to inhibit endogenous peroxidase, washed in PBS and then transferred to $0.1 \mathrm{M}$ sodium citrate buffer at $90^{\circ} \mathrm{C}$ for 5 min to unmask antigens. After cooling, section were washed in $0.1 \mathrm{M}$ PBS, preincubated in 0.1 normal goat serum at room temperature for $20 \mathrm{~min}$, and then incubated with the anti-AM primary antibodies (1:1000 dilution, paraffin sections; 1:100 dilution 2- $\mu \mathrm{m}$ sections) at $4{ }^{\circ} \mathrm{C}$ overnight. After repeated PBS washing, sections were incubated for $30 \mathrm{~min}$ at room temperature with the secondary antibody (1:40 dilution). Sections were rinsed, and the reaction developed for $5 \mathrm{~min}$ with Sigma DAB tablets, and stopped with water. Negative controls were carried out by similarly treating adjacent sections and either omitting the primary antibody or by using primary antibodies preabsorbed with antigen excess (9). Specimens were observed and photographed with a camera-connected Leitz Laborlux microscope. Ultrathin sections were floated for $15 \mathrm{~min}$ at $90^{\circ} \mathrm{C}$ on a drop of PBS to unmask antigens, then they were processed as detailed above, using anti-rat AM primary and immunogold-conjugated secondary antibodies (dilution 1:100). After rinsing and washing in PBS and bidistilled water, grids were counter-stained with $2 \%$ uranyl acetate for $2 \mathrm{~min}$ at $50^{\circ} \mathrm{C}$ and then with Sato's lead for $30 \mathrm{sec}$ at room temperature. Specimens were observed in a Hitachi H-300 transmission electron microscope.

Adrenomedullin assay. AM concentration was measured using the AM1-50 RIA kit purchased from Phoenix Pharmaceuticals. AM was extracted from incubation media, and purified on Sep-Pak C18 cartridge, following the manufacturer's protocol: sensitivity, about $5 \mathrm{fmol} / \mathrm{ml}$; cross reactivity, rat AM, 100\%, and human AM and other peptides, $0 \%$; intra- and interassay $\mathrm{CVs}, 6 \%$ and $8 \%$, respectively. Data were normalized per $\mathrm{mg}$ of incubated tissue fragments, and expressed as means \pm SD $(n=8)$. The statistical comparison was done by ANOVA followed by the Dunnet test.

\section{Results}

ICC carried out on paraffin sections showed the presence of sparse AM-positive cells near coronary vessels of both rat and human heart. AM immunostaining was also detected in the wall of coronary arterioles and in cardiomyocytes (Fig. 1). Using 2- $\mu \mathrm{m}$ sections, AM-storing cells had the same juxtavascular location of toluidine blue-stained mast cells (Fig. 2). However, not all mast cells were AM positive. Electron microscopy demonstrated that anti-AM immunogold was located over the granules of rat cardiac mast cells (Fig. 3).

The incubation with the compound 48/80 decreased the number of both toluidine blue- and AM-positive cells in the rat left ventricle (data not shown), in keeping with our expectations (7). Sometimes, groups of AM-storing cells undergoing degranulation were observed: granules were less compactly arranged in the cytoplasm and AM positivity was 


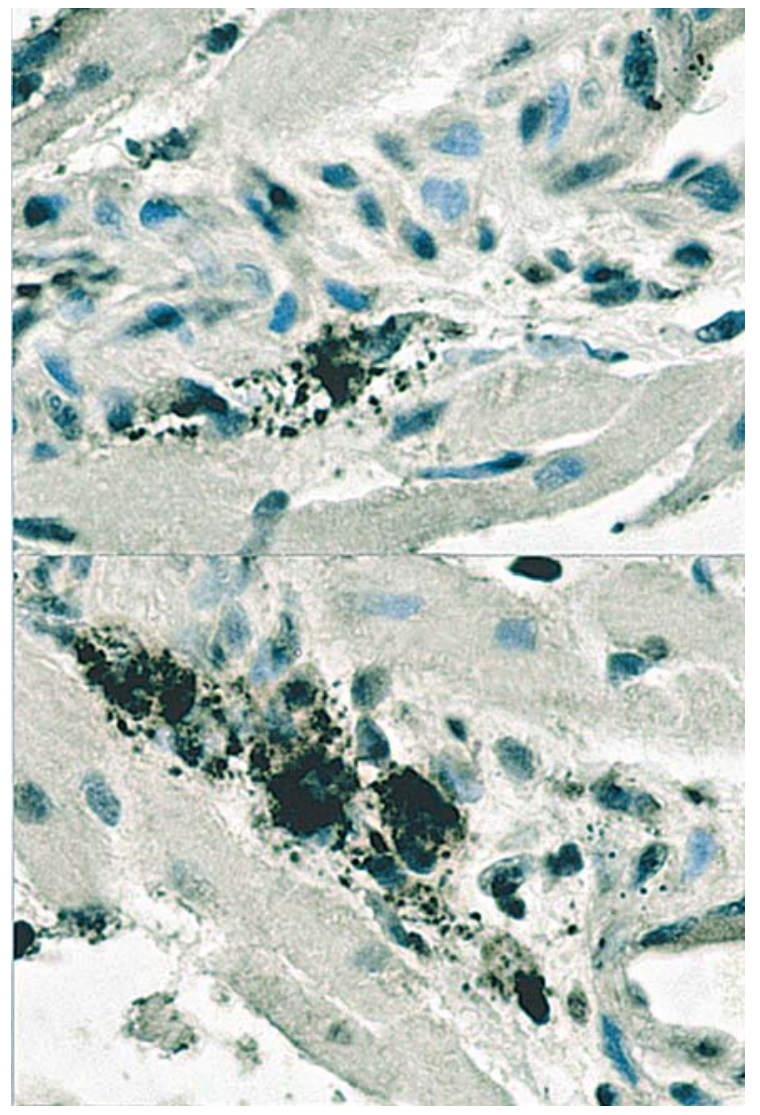

Figure 4. Paraffin sections $(6-\mu \mathrm{m})$ of rat left ventricle fragments incubated for $30 \mathrm{~min}$ in Krebs-Ringer bicarbonate buffer not containing (upper panel) or containing $50 \mu \mathrm{g} / \mathrm{ml}$ compound 48/80 (lower panel), showing AM-storing (DAB-positive) cells located near coronary vessels $(*)$. Compared with the controls (Fig. 1), AM-storing cells of compoud 48/80-treated fragments occasionally show a less compact arrangement of granules, some of which appear to be released in the perivascular space. Magnification x650.

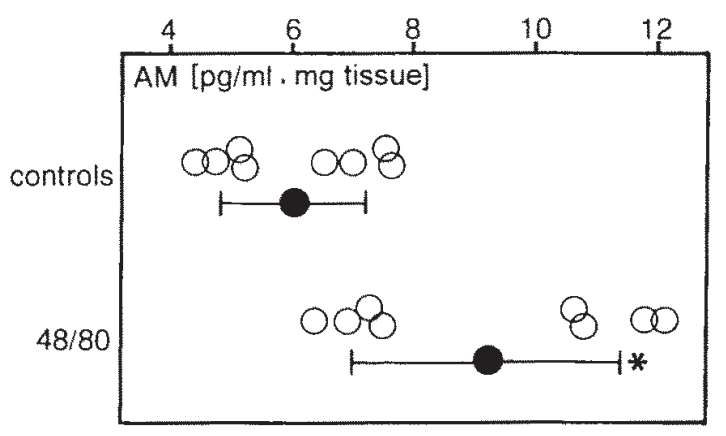

Figure 5. Effect of compound 48/80 on the AM concentration in the incubation media of rat left ventricle fragments. Solid circles indicate mean values \pm SD. ${ }^{*} \mathrm{P}<0.01$ from control group.

present in the perivascular extracellular space (Fig. 4). RIA showed that incubation with compound $48 / 80$ raised by about $50 \%$ AM concentration in the incubation medium of rat left ventricle fragments (Fig. 5).

\section{Discussion}

Our present study confirms the presence of AM-storing cells in the rat heart $(3,7)$, and extends this finding also to the human cardiac tissue. Moreover, it provides proof that these cells belong to a subpopulation of cardiac mast cells. In fact: i) AM-positive cells stain like mast cells with toluidine blue (8); ii) AM-positive material is contained in cardiac mast cell granules; and iii) compound 48/80, a specific histamine releaser and mast cell degranulator (10), induces degranulation of AMstoring cells and raises AM concentration in the incubation medium of rat heart fragments.

These findings are not totally unexpected, because the functional heterogeneity of mast cells is well recognized. Mast cells, in addition to storing and releasing histamine and heparin, are also able to synthesize growth factors (11) and other regulatory peptides, including ET-1 (12), CRH (13) and renin (14). Our results indicate that AM may be added to the list of peptides stored in mast cells, thereby confirming the earlier finding that rat peritoneal mast cells express the AM gene (15).

The functional relevance of our observations remains to be elucidated. However, we recall that AM exerts a major cardiac protective action, its expression being up-regulated in various heart diseases, including left ventricular hypertrophy, myocardial infarction and congestive heart failure $(2,16)$. The beneficial effects of AM ensue from its NOmediated coronary vasodilatory action $(17,18)$, its ability to counteract cardiac fibrosis (19-21), and its relevant proangiogenic activity $(22,23)$. Compelling evidence is available that mast cells are involved in the regulation of coronary vascular tone (24), myocardial remodeling $(25,26)$, and angiogenesis (27-29). The perivascular location of these AM-storing mast cells and their previously shown capability to respond to vasoactive stimuli as ET-1 (7) are consistent with their important paracrine role in the regulation of coronary circulation under both physiological and pathophysiological conditions.

\section{References}

1. Lopez $\mathbf{J}$ and Martinez A: Cell and molecular biology of the multifunctional peptide adrenomedullin. Int Rev Cytol 221: $1-92,2002$.

2. Eto T, Kato J and Kitamura K: Regulation of production and secretion of adrenomedullin in the cardiovascular system. Regul Pept 112: 61-70, 2003.

3. Belloni AS, Guidolin D, Ceretta S, Bova S and Nussdorfer GG: Acute effects of endothelins on endogenous adrenomedullin system in the rat heart: immunocytochemical and autoradiographic studies. Int J Mol Med 13: 669-674, 2004.

4. Belloni AS, Guidolin D, Ceretta S, Bova S and Nussdorfer GG: Acute effects of ischemia on adrenomedullin immunoreactivity in the rat heart: an immunocytochemical study. Int J Mol Med 14: 71-73, 2004.

5. Welsch U, Unterberger P, Höfter E, Cuttitta F and Martinez A: Adrenomedullin in mammalian and human skin glands including the mammary gland. Acta Histochem 104: 65-72, 2002.

6. Martinez A, Saldise L, Ramirez MJ, Belzunegui S, Zudaire E, Luquin MR and Cuttitta F: Adrenomedullin expression and function in the rat carotic body. J Endocrinol 176: 95-102, 2003.

7. Belloni AS, Guidolin D, Salmaso R, Bova S, Rossi GP and Nussdorfer GG: Adrenomedullin, ANP and BNP are colocalized in a subset of endocrine cells in the rat heart. Int J Mol Med 15: $567-571,2005$.

8. Brower GL, Chancey AL, Thanigaraj S, Matsubara BB and Janicki JS: Cause and effect relationship between myocardial mast cell number and matrix metalloproteinase activity. Am J Physiol 283: H518-H525, 2002.

9. De Angeli S, Di Liddo R, Buoro S, Toniolo L, Conconi MT, Belloni AS, Parnigotto PP and Nussdorfer GG: New immortalized human stromal cell lines enhancing in vitro expansion of cord blood hematopoietic stem cells. Int J Mol Med 13: 363-371, 2004. 
10. Koibuchi Y, Ichikawa A, Nakagawa M and Kenkichi T: Histamine release induced from mast cells by active components of compound 48/80. Eur J Pharmacol 115: 163-170, 1985.

11. Crivellato E, Beltrami CA, Mallardi F and Ribatti D: The mast cell: an active participant or an innocent bystander? Histol Histopathol 19: 259-270, 2004.

12. Hultner L and Ehrenreich H: Mast cells and endothelin-1: a lifesaving biological liason? Trends Immunol 26: 235-238, 2005

13. Kempuraj D, Papadopoulou NG, Lytinas M, Huang M, Kandere-Grzybowska K, Madhappan B, Boucher WS, Christodoulou S, Athanassiou A and Theoharides TC: Corticotropin-releasing hormone and its structurally related urocortin are synthesized and secreted by human mast cells. Endocrinology 145: 43-48, 2004

14. Silver RB, Reid AC, Mackins CJ, Askwith T, Schaefer U, Herzlinger D and Levi R: Mast cells: a unique source of renin. Proc Natl Acad Sci USA 101: 13607-13612, 2004.

15. Yoshida M, Yoshida H, Kitaichi K, Hiramatsu K, Kitamura T, Ito Y, Kume H, Yamaki K, Suzuki R, Shibata E, Hasegawa T and Takagi K: Adrenomedullin and proadrenomedullin Nterminal 20 peptide induce histamine release from rat peritoneal mast cells. Regul Pept 101: 163-168, 2001.

16. Hamid SA and Baxter GF: Adrenomedullin: regulator of systemic and cardiac homeostasis in acute myocardial infarction. Pharmacol Ther 105: 95-112, 2005.

17. Terata K, Miura H, Liu Y, Loberiza F and Gutterman DD Human coronary arteriolar dilation to adrenomedullin: role of nitric oxide and $\mathrm{K}^{+}$channels. Am J Physiol 279: H2620-H2626, 2000.

18. De Matteo R and May CN: Direct coronary vasodilator action of adrenomedullin is mediated by nitric oxide. Br J Pharmacol 140: 1414-1420, 2003

19. Niu P, Shindo T, Iwata H, Iimuro S, Takeda N, Zhang Y, Ebihara A, Suematsu Y, Kangawa K, Hirata Y and Nagai R: Protective effects of endogenous adrenomedullin on cardiac hypertrophy, fibrosis, and renal damage. Circulation 109: 1789-1794, 2004.
20. Nishikimi T, Tadokoro K, Akimoto K, Mori Y, Ishikawa Y, Ishimura K, Horio T, Kangawa K and Matsuoka M: Response of adrenomedullin system to cytokine in cardiac fibroblasts. Role of adrenomedullin as an antifibrotic factor. Cardiovasc Res 66: 104-113, 2005.

21. Tsuruda T, Kato J, Hatakeyama K, Masuyama H, Cao YN, Inamura T, Kitamura K, Asada Y and Eto T: Antifibrotic effect of adrenomedullin on coronary adventitia in angiotensin IIinduced hypertensive rats. Cardiovasc Res 65: 921-929, 2005.

22. Nagaya N, Mori M, Murakami S, Kangawa K and Kitamura S: Adrenomedullin: angiogenesis and gene therapy. Am J Physiol 288: R1432-R1437, 2005.

23. Ribatti D, Nico B, Spinazzi R, Vacca A and Nussdorfer GG: The role of adrenomedullin in angiogenesis. Peptides 26: 1670-1675, 2005.

24. Ginsburg R, Bristow MR and Davis K: Receptor mechanisms in the human epicardial coronary artery. Heterogeneous pharmacological response to histamine and carbacol. Circ Res 55: 416-421, 1984.

25. Murray DB, Gardner JD, Brower GL and Janicki JS: Endothelin-1 mediates cardiac mast cell degranulation, matrix metalloproteinase activation, and myocardial remodeling in rats. Am J Physiol 287: H2295-H2299, 2004

26. Upadhya B, Kontos JL, Ardeshirpour F, Pye J, Boucher WS, Theoharides TC, Dehmer GJ and Deliargyris EN: Relation of serum levels of mast cell tryptase to left ventricular systolic function, left ventricular volume or congestive heart failure. J Card Fail 10: 31-35, 2004.

27. Norby K: Mast cells and angiotensins. APMIS 110: 355-371, 2002 .

28. Lappalainen H, Laine P, Pentikainen MO, Sajantila A and Kovanen PT: Mast cells in neovascularized human coronary plaques store and secrete basic fibroblast growth factor, a potent angiogenic mediator. Arterioscler Thromb Vasc Biol 24: 1880-1885, 2004.

29. Matsumori A: Role of hepatocyte growth factor and mast cells in thrombosis and angiogenesis. Cardiovasc Drugs Ther 18: 321-326, 2004. 